\title{
EJSBS
}

The European Journal of Social \&

Behavioural Science

ISSN: 2301.2218 (ONUINE)
OPEN ACCESS

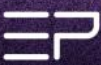

The European Journal of Social and Behavioural Sciences

EJSBS Volume XXX, Issue III (eISSN: 2301-2218)

\section{TEACHER PREFERENCES OF LITERATURE CURRICULA AT HIGHER SECONDARY SCHOOLS IN THE CZECH REPUBLIC}

\author{
Michal Čuřín ${ }^{\mathrm{a}}$, Michala Mikolášíkováa* \\ ${ }^{a}$ University of Hradec Kralove, Faculty of Education, Rokitanskeho 62, 50003 Hradec Kralove, Czech Republic
}

\begin{abstract}
The current revision of national curricula documents in the Czech Republic is motivated by the increasing digitalization of society as well as the need to prepare students for future challenges linked with economic restructuring. The revision includes the reduction of teaching content as well as the establishment of a new range of student learning outcomes. This paper focuses on identifying teacher preferences with regard to the literature curriculum in terms of the curricular content and scope at higher secondary schools. Based on a thorough content analysis of current school curricula documents and textbooks, a socalled model maximum curriculum of literature was established as a basis for the construction of a questionnaire for teachers to express their preferred content. 20 secondary school teachers were selected according to their gender, type of school and duration of working experience as the sample for this study. The analysis found that teachers are satisfied with the current curriculum in terms of content and scope. However, two common tendencies were observed. Firstly, the majority of respondents agreed on the reduction of the curricular content devoted to older literature. Secondly, the reduction of curricular content was consistent in rejecting foreign thematic blocks and minor national literatures. The analysis also confirmed the teachers' lack of interest in including Asian, African, and Central and South American literature in the curriculum.
\end{abstract}

Keywords: Literature curricula, secondary schools, teacher preferences

C) 2021 Published by European Publisher. www.europeanpublisher.com

\footnotetext{
${ }^{*}$ Corresponding author.

E-mail address: michala.mikolasikova@uhk.cz
} 


\section{Introduction}

In the context of social, cultural and environmental changes, the rapid development of digital technologies and the concurrent transformation of the economy, the Czech Republic is currently undertaking an in-depth revision of curriculum documents with a view to the next 10 years and beyond (see Fryč et al., 2020). These revisions are being undertaken to emphasise the fundamental position of key educational competences in accordance with the Recommendations of the Council of the European Union (2018), as well as the new structure of curriculum content. The initial position of the revision operates on the assumption that the curriculum is currently overloaded, leading to the premise that key knowledge is not sufficiently practised resulting in a lack of understanding and application of key knowledge by the students. The revised national curriculum will thus distinguish between core knowledge, which will be given special attention in teaching, and peripheral knowledge, which will be an additional but optional part of teaching. Although the political representation proclaims the broad involvement of the teaching community in the ongoing curriculum revision, teachers' attitudes and ideas about the changes in the scope of the curriculum are not systematically monitored. In our study, therefore, we focus on ascertaining teachers' preferences in their curricular choices, specifically in teaching literature at higher secondary schools. Teachers are a vital contributing element to the successful implementation of any curriculum as they are the conduit through which curricular objectives are successfully realised in student learning outcomes. In fact, Alsubaie (2016) contends that:

Without doubt, the most important person in the curriculum implementation process is the teacher. With their knowledge, experiences and competencies, teachers are central to any curriculum development effort. Better teachers support better learning because they are most knowledgeable about the practice of teaching and are responsible for introducing the curriculum in the classroom. (p.106)

The issue of teaching literature and partial or complete dissatisfaction with its content has been a subject of interest for professionals in Czech society for more than a hundred years (cf. e.g., Schauer, 1890). However, critics of the current concept of teaching literature have emphasised different types of literature in different periods depending on their political, religious or worldview positions. If it is possible to identify a consistent concept that critics have highlighted, it is mainly related to the irrelevance of what is taught in contrast to the authentic interests of the students. It is mainly this mismatch between the students' actual reading preferences and the literary works taught in schools that is of concern to critics. If teaching of classical literature is prioritised, then less space would be devoted to reading books 
and literary magazines which students may prefer, which leads students to regard the content of such lessons as uninteresting and not substantially relevant to their lives.

The teaching of literature and the discussion about its direction is not only at the centre of the debate among Czech teachers, but this tendency to reassess the content and form of teaching and to adapt it to the interests and needs of contemporary students, within the context of the digital revolution, is also evident in other countries. The triggers for change may be attributed to external stimuli such as unsatisfactory results in international PISA tests (Frederking, 2005; Anselm, 2020), environmental issues (Myren-Svelstad, 2020), social and cultural shifts (Kenyon \& Christoff, 2020), or internal updates driven by a desire to improve the teaching process as a whole (Sosnowski, \& Tendera, 2015; Fischer \& da Silva, 2018; Spinner, 2019).

The Czech education system and specific teaching practices are mainly determined by two curricular documents. At the state level, it is the framework curricula for individual streams of education, which, in general terms, refer to the curriculum for specific educational areas, key competences and expected outcomes at certain stages of schooling, etc. Within the boundaries set by these documents, each school then specifies its own school curriculum, which already regulates in detail the actual teaching practice. It should be pointed out that, in terms of the curriculum, the national framework in the field of literature is quite general and thus, allows individual schools considerable freedom to adjust the scope of the curriculum. The teaching of literature has been included in the Czech education system since the beginning of schooling, mainly to support reading, after which, it becomes independent as a coherent block, usually as part of the teaching of Czech language and style. In lower secondary education, the focus in teaching literature is on strengthening reading competences, skills in handling texts, basic literary theory and a brief literary-historical overview. Most schools follow the genres that dominate each year of this level of education - e.g., fairy tales, children's stories which include a child as the protagonist, etc. (EurydiceEu, 2017)

Upper secondary education in the Czech Republic is of three types. There are schools that are oriented for a specific occupation, ending with a VET certificate (two- and three-year education) or the Maturita examination (usually four-year education), and schools providing general education (four-year education), always ending with the Maturita examination, which orient their graduates for specialisation studies in tertiary education. In upper secondary education, the teaching of literature focuses on literary-historical instruction, although the national curriculum does not give this component any priority over others (such as knowledge of one's own position in the socio-historical context, building a relationship with the aesthetic object and making a relevant assessment of it, applying informed ways of analysing and 
https://doi.org/10.15405/ejsbs.306

eISSN: 2301-2218 / Corresponding Author: Michala Mikolášiková

Selection \& Peer-review under responsibility of the Editors

interpreting the text, etc.). The teaching of literary history is usually done in a chronological sequence, but individual schools are authorised to decide how to organize the curriculum (National Institute for Education, n.d).

\section{Problem Statement}

According to Alsubaie (2016),

The goal of a successful educational program and thus effective curriculum development should be to meet the needs and current demands of the culture, the society, and the expectations of the population being served. Therefore, curriculum development and the educational reform process continually undergoes review, revision, and constant change (p. 106).

Such changes are deemed as essential given the dynamic nature of socio-economic, cultural, and technological advances sweeping through all nations across the world. Failure to keep abreast of these changes through revised educational outcomes would spell a disaster for the socio-economic, cultural and technological development of any nation.

With regard to the current revision of the national curriculum documents in the Czech Republic, the changes largely affect the content and scope of the curriculum. In order for the transformation of educational content to not only be formally implemented but also accepted by teachers, it is necessary to ascertain teachers' perceptions and preferences with regard to the changes (Carl, 2009). The importance of teachers' input in curricular revisions has already been established above. We, therefore, consider it essential to ascertain literature teachers' contribution to curricular change or whether they are willing to actively intervene in the current situation at all.

\section{Research Questions}

1. Does the scope and structure of the curriculum differ depending on the type of educational field?

2. What subject areas do teachers of literature consider to be excessive?

3. What areas of the curriculum would they prioritise and expand, what areas would they omit and what subject areas are missing in their teaching?

4. Can some common phenomena be traced in the teachers' responses?

5. Can correlations be identified between teachers' age and length of experience, type of school and responses related to curriculum content? 
https://doi.org/10.15405/ejsbs.306

eISSN: 2301-2218 / Corresponding Author: Michala Mikolášiková

Selection \& Peer-review under responsibility of the Editors

\section{Purpose of the Study}

The purpose of the present study is to identify the scope of the literature curriculum in upper secondary education based on an analysis of available school curriculum documents. Furthermore, through the application of a self-designed questionnaire, the research aims to uncover the perceptions of literature teachers towards the scope of the curriculum.

\section{Research Methods}

\subsection{Sample}

In selecting respondents, we focused on teachers in upper secondary education. In terms of the representation of women and men in the sample, we aimed for gender parity, which roughly corresponds to the current representation of both genders among teachers in upper secondary education in the Czech Republic. The number of respondents was adjusted to the number of different schools in the East Bohemian region where the research took place. Due to regional limitations and the small number of respondents, the sample cannot be considered as representative of the whole population. The investigation worked with a total sample of 20 participants, $75 \%$ of whom were women. The design of the survey was intended to cover all streams of upper secondary education, i.e. both general education aimed preferably at preparing for university studies and vocational education preparing students preferably for a specific profession. A total of 8 completed questionnaires were received from general education teachers, and 12 completed questionnaires were received from vocational school teachers, giving a response rate of $100 \%$. The territorial aspect did not play a role in the selection of the sample; due to the location of upper secondary schools in larger settlements, this characteristic is reflected in our research. The last criterion was the length of teaching experience where only teachers with more than 10 years of experience were included in the research. This limitation is justified by the ability of the respondents to assess, on the basis of their own teaching activities, the relevance of the inclusion of particular thematic blocks in the teaching of literature.

\subsection{Research procedure}

The investigation was designed as a mixed-methods study using both qualitative and quantitative components with data collected through document analysis and a questionnaire. The questionnaire was designed specifically for the purpose of this investigation; the reason being that this investigation focused on a particular component of the curriculum - the literature component - and was limited to the current curriculum revision within the Czech 
https://doi.org/10.15405/ejsbs.306

eISSN: 2301-2218 / Corresponding Author: Michala Mikolášiková

Selection \& Peer-review under responsibility of the Editors

Republic. This precluded using questionnaires from other studies as the research objectives of this study and other studies were dissimilar. Using instruments from other studies would necessitate significant revision and adaptation of the questionnaire to meet the needs of this investigation; hence, we decided that it would be more convenient to develop our own questionnaire.

To develop this questionnaire, we used a large collection of school curriculum documents (72 in total) from different geographical areas and different educational streams that describe the content of the literature component in secondary schools from a thematic perspective. Selected secondary school literature textbooks were also examined as supplementary material. The resulting analysis contributed a set of themes covering the entire scope of the literature component in secondary schools. As already mentioned, the teaching of literature in Czech schools is implemented in a chronological sequence (from the oldest literary works to the most recent; although other arrangements, e.g. thematic, are not excluded). Hence, the questionnaire was also constructed based on this sequence - i.e. from general instruction about literature and literary science, through the oldest literary monuments, ancient fiction, medieval writing, etc. to the most recent literary artefacts. Larger thematic blocks (such as the literature of the Romantic period) were usually more detailed in school curriculum documents (English, Russian, German Romantic literature, etc.), so respondents had these options as well in our questionnaire. The nature of the investigation precluded any reference in the questionnaire to the competence aspects such reading comprehension and critical reading skills and focused exclusively on factual knowledge of literary components.

In order to elicit the necessary information to answer the research questions, the questionnaire was designed in such a way that allowed respondents to modify this maximum set of topics according to their perceptions about the necessary literature content for high school aligned to the educational streams they were professionally involved in. Adaptation could take place in three ways. Firstly, respondents could cross out an entire topic block or just one specific part of it, or more than one of these parts. Secondly, they could use the symbols available to them to indicate a particular area as particularly important, which should be given more space during teaching, and conversely, they could indicate an area/areas which should be omitted. Thirdly, respondents were given the opportunity to suggest any learning content that needed to be included in the revised curriculum.

The processing of the survey consisted primarily in identifying patterns linking the removed or retained thematic areas, and eliminating outliers and individual differences, while monitoring possible correlations between responses and categories of respondents. 
https://doi.org/10.15405/ejsbs.306

eISSN: 2301-2218 / Corresponding Author: Michala Mikolášiková

Selection \& Peer-review under responsibility of the Editors

\section{Findings}

Due to the size of the research sample, it was not possible to draw relevant conclusions regarding the preferences of subject blocks or individual topics among teachers of different educational streams in relation to the whole education system. Also, the data analysis does not provide a clear answer as to whether the age of teachers or the length of their experience are in any way correlated with their perception of the content of the subject taught. Hence, no correlation could be identified between teachers' age, length of experience, type of school and their responses related to curriculum content.

On the other hand, we feel that the survey provided interesting findings on trends in teachers' perceptions about curriculum content. Hence, related to the research question on areas of the curriculum they would prioritise and expand, they would omit and areas missing in their teaching, the majority of the respondents (95\%) agree on the reduction of older literature (whether at the level of whole blocks or individual topics) and on the strengthening of the role of contemporary world and Czech literature. When it comes to the reduction of educational content, $80 \%$ of the respondents are in favour of reducing the representation of foreignlanguage literature in the curriculum. We also observed an interesting tendency characterised by the deletion or reduction of Central European literatures (i.e. Polish, Hungarian, Austrian) and Russian literature in the blocks that directly offered this distinction (e.g. realistic and romantic literature, avant-garde, etc.), while the so-called great literatures were not affected by this reduction and, as we have mentioned, Czech literature only rarely. In the area of teaching literary theory in secondary school, the only significant consensus among the respondents related to the neglect of the role of the doctrine of prosody. Areas of the questionnaire for adding additional content to be included in the teaching were unused.

\section{Discussion and Conclusion}

The investigation was exploratory in nature and will provide, we hope, the impetus for the future research to document the phenomena holistically within the entire education system on a more representative sample. Despite the small sample, we managed to identify some important trends that we consider worthy of interest. In terms of expanding the research sample, we consider it useful in the future, to include student teachers before they start their teaching practice, who have not yet been exposed to the institution's pressure to conform and whose own ideals and ideas about the proper teaching practice have not yet been confronted with the real operation of school organizations. We believe this would contribute a valuable insight to the area under investigation. 
As noted above, the majority of respondents (regardless of educational stream) were in favour of expanding the teaching of contemporary literature in secondary schools. This finding, however, contrasts sharply with our previous research (Čuřín, 2013), which attempted to determine the actual state of teaching in terms of the content of literature curricula for secondary schools based on the mandatory published documents ${ }^{1}$ for the secondary school final examination. This current investigation revealed that the actual teaching practice emphasizes older literature and completely neglects contemporary literary works of art. The discrepancy between these findings is highlighted primarily in the different research design. Whereas the previous (Čuřín, 2013) survey was deliberately based on the analysis of documents that indirectly confirm actual teaching practice and eliminated direct questioning of individual teachers, the current survey is based on the testimonies of teachers who are directly involved in teaching. It can therefore be reasonably assumed that their statements anticipate expected or desired responses, as they are aware, based on their own experience and also on the prevailing discourse of academic (or educational policy, as discussed in the introduction) policy, of the inherent interest of students in actual - lived - cultural production, and with it the need to reduce other teaching foci. Thus, there appears to be a discrepancy between teachers' proclamations and ideas about teaching and their actual teaching practice.

The respondents were mostly in favour of reducing some of the lower-level thematic blocks, which included Central European literature, compared to no reduction at all of socalled majoritarian literatures (e.g. Anglo-American, German, French). This trend can be understood in the context of the overall construction of the curriculum which is largely EuroAmerican culturally-centric. Thus, African and Asian literatures are absent from the curriculum (with some minor exceptions of Chinese classical literature), and some Central and South American literatures are marginally included, despite the fact that important works of classical and contemporary literary tradition of the aforementioned regions are available in translation and there is sufficient scholarly reflection on these literatures. The dangers arising from lack of representation of literatures from outside our own cultural circle and the neglect of 'lesser' or smaller national literatures in the curriculum can result in students having a distorted view of their own culture or to consider their culture as exceptional or superior, etc. ${ }^{2}$ Furthermore, such a lack of exposure to other literatures may also lead to overlooking or sidelining the problems, ideas and distinctive artistic expressions characteristic of a large part of the planet's population. As Wolf (2019) argues, reading literary texts is an effective and difficult-to-replace means of fostering empathy, so if nationality or cultural proximity is the

\footnotetext{
${ }^{1}$ These are lists of literary works of art compiled by teachers based on their own preferences, from which students then select 20 literary works that form the basis of a section of their final high school exam.

${ }^{2}$ Compare Boyd et al. (2014).
} 
measure of learning about global cultural heritage in today's interconnected world, it will not contribute to much-needed mutual understanding. Understandably, any malice or bad intent should not be misconstrued on the part of teachers in responding as they did. Rather, the problem lies in the traditionalist undergraduate teacher education, which has so far emphasized the teaching of national literature for literature teachers, as well as in the absence of support for teachers in their postgraduate training, which would enable them to become regularly acquainted with the latest literary works and significant literary artifacts outside the EuroAmerican cultural sphere. This investigation confirms that teachers are interested in this content, even if they do not yet include it in their teaching preferences.

It is also surprising that teachers opted to limit the representation of Central European literatures, to which Czech literature is close because of the commonalities in their history, customs and long-standing functioning in a common state. As already mentioned, this is not apparent in the case of the so-called great literatures, as evidenced by the well-known Matthew effect. The position of those literatures firmly established on the global market, literatures translated, reflected and processed by other types of media (film, computer games) is strengthening, while the position of the so-called 'lesser' literatures is slipping, regardless of geographical or cultural proximity. This phenomenon can be documented especially in the position of Slovak literature in Czech curriculum documents. Czech and Slovak cultures have always been close to each other; both languages are easily understood by the majority of speakers. This was especially so during the existence of the independent Czechoslovak state when mutual cultural exchange was encouraged and the teaching of literary history of both nations was strengthened. After the collapse of the common state in 1993 however, these trends were drastically reduced and we can now state that the representation of Slovak literature in Czech textbooks is indeed sporadic and Slovak literature never appeared in the school curriculum documents we analysed. Hence, it was not represented in our questionnaire, nor did teachers feel the need to add it as an additional unlisted subject.

Based on the above analysis and conclusions, a hypothesis (that should be confirmed by further investigation) can be developed; that is, that two clear clashing tendencies emerge in the teachers' perceptions regarding the necessary curricular content in the revised curriculum. Firstly, teachers have opted for the elimination of so-called lesser, national literatures, regardless of geographical proximity and cultural affinity. Secondly, they have displayed a preference for so-called greater, established literatures with a combined aspect of geographical proximity and European-American cultural affinity.

The implications of this investigation, though with a limited sample, are far-reaching as it reveals that teacher' perceptions on what they deem important and unimportant as 
https://doi.org/10.15405/ejsbs.306

eISSN: 2301-2218 / Corresponding Author: Michala Mikolášiková

Selection \& Peer-review under responsibility of the Editors

teaching content in the literature curriculum. Teachers' preferences in terms of curricular content need to be addressed as they are solely responsible for transforming curricula objectives into teaching content. It is ultimately in the hands of teachers as to whether the curricular objectives will be successfully operationalised into student learning outcomes; thus, their insights are invaluable and inextricable from any curricula development and revision.

\section{Acknowledgments}

The contribution is financially supported by a grant of the Specific research of the Faculty of Education of the University of Hradec Kralove (No. 2119/01310/1210). The author(s) declare that there is no conflict of interest.

\section{References}

Alsubaie, M. A. (2016). Curriculum Development: Teacher Involvement in Curriculum Development. Journal of Education and Practice, 7(9), 106-107. https://files.eric.ed.gov/fulltext/EJ1095725.pdf

Anselm, S. (2020). 20 Jahre PISA-Schock - Literatur(unterricht) als Zumutung?! [20 years of PISA shock - literature (teaching) as an imposition?!] Mitteilungen des Deutschen Germanistenverbandes, 67(1), 34.

Boyd, F., Causey, L., \& Galda, L. (2014). Culturally Diverse Literature. The Reading Teacher, 68. https://doi.org/10.1002/trtr.1326

Carl, A. (2009). Teacher empowerment through curriculum development: Theory into Practice. Juta \& Company Ltd.

Čuřín, M., \& Bubeníčková, P. (2013). Čtenářství v souvislostech [Reading in context]. Oftis.

Doporučení Rady ze dne 22. května 2018 o klíčových kompetencích pro celoživotní učení [Recommendations of the Council of the European Union Key Features of the Education System of the Czech Republic [Text]. Eurydice - European Commission. https://eacea.ec.europa.eu/national-policies/eurydice/content/czech-republic_en

Fischer, R., \& da Silva, T. (2018). Literature and education: The pleasure of the text in between the margins of the school system. Revista Brasileira de Educacao, 23. https://doi.org/10.1590/S1413-24782018230097

Frederking, V. (2005). Deutschdidaktik und Deutschunterricht nach PISA. Eine Bestandsaufnahme nebst einigen hochschul- und bildungspolitischen Anmerkungen [German Didactics and German Teaching after PISA. A stocktaking together with some comments on higher education and educational policy]. https://doi.org/10.1007/978-3322-80658-1_8

Fryč, J., Matušková, Z., Katzová, P., Kovář, K., Beran, J., Valachová, I., Seifert, L., Bět’áková, M., \& Hrdlička, F. (2020). Strategie vzdělávací politiky České republiky do roku 2030+ [Education Policy Strategy of the Czech Republic until 2030+]. Ministerstvo školství, mládeže a tělovýchovy.

Kenyon, E., \& Christoff, A. (2020). Global citizenship education through global children's literature: An analysis of the NCSS Notable Trade Books. The Journal of Social Studies Research, 44(4), 397-408. https://doi.org/10.1016/j.jssr.2020.05.001 
National curricula, National Institute for Education. (s.a.). Retrieved 6 February 2021, from http://www.nuv.cz/our-work/framework

Odbor informatiky a statistiky MŠMT. (2021). Statistická ročenka školství-2019/2020 Výkonové ukazatele [Statistical Yearbook of Education-2019/2020-Performance indicators]. http://toiler.uiv.cz/rocenka/rocenka.asp

Myren-Svelstad, P. E. (2020). Sustainable Literary Competence: Connecting Literature Education to Education for Sustainability. Humanities, 9(141), 141-141. https://doi.org/10.3390/h9040141

Schauer, H. G. (1890). Literatura a literární dějepis [Literature and literary history]. Literární listy, 11(23), 385-387.

Sosnowski, L., \& Tendera, P. (2015). The Polish Horizon in Education-Facts and Fiction. Procedia - Social and Behavioral Sciences, 174, 3428-3433. https://doi.org/10.1016/j.sbspro.2015.01.1014

Spinner, K. H. (2019). Literaturunterricht zwischen Instruktion und Individualisierung [Teaching literature between instruction and individualization]. In Deutsch-Didaktik: Praxishandbuch für die Sekunsarstufe I und II. Cornelsen.

Wolf, M. (2019). Reader, come home: The reading brain in a digital world. Harper. 